\title{
Angka Paling Mungkin (Most Probable Number/MPN) Coliform Sampel Kue Bingke Berendam di Pontianak
}

\author{
Dini Agustin ${ }^{1}$, Rahmawati ${ }^{1}$,Elvi Rusmiyanto P.W ${ }^{1}$ \\ Program Studi Biologi, Fakultas MIPA, Universitas Tanjungpura, Jl. Prof. Dr. H. Hadari Nawawi, Pontianak, \\ Email korespondensi: diniiagustin@gmail.com
}

\begin{abstract}
Bingke berendam cake is one of the traditional foods of Pontianak which is made from rice flour, eggs, sugar and coconut milk. Materials that are used such as sugar, milk and eggs are ingredients that are easily damaged and polluted by microbes. This study aimed to to find out the Most Probable Number (MPN) of coliform bacteria in bingke cakes. Taking bingke cake samples was done at five bingke cake shops in Pontianak city. Isolation of Coliform bacteria used the MPN method, with two stages, namely the estimator test tand the assertive test. Based on the results of this study, the five samples had MPN values ranging from $23 \mathrm{MPN} / \mathrm{g}$ to> $100 \mathrm{MPN} / \mathrm{g}$. All samples had MPN values that exceed the threshold so that they did not meet the requirements for PERKA BPOM No. 16 of 2016, which is a $11 \mathrm{MPN} / \mathrm{g}$.
\end{abstract}

Kata kunci: Bingke Berendam, Coliform, MPN

\section{PENDAHULUAN}

Makanan tradsional pada umumnya memiliki kelemahan dalam hal keamanannya terhadap bahaya biologis atau mikrobiologis, kimiawi, dan fisikawi. Pengolah makanan umumnya kurang memperhatikan kebersihan dalam menghasilkan makanan yang higienis. Salah satu golongan bakteri yang dapat mengkontaminasi makanan, yaitu golongan Coliform (Depkes, 2002). Coliform merupakan bakteri indikator keberadaan bakteri patogenik. Bakteri golongan Coliform merupakan golongan mikroorganisme yang dapat berasal dari kotoran manusia atau hewan, air, maupun makanan. Adanya bakteri golongan Coliform di dalam makanan atau minuman dapat membahayakan kesehatan (Widiyanti \& Ristiati, 2004), karena dapat menyebabkan penyakit, seperti diare, demam, mual muntah dan gangguan pencernaan lainnya (Entjang, 2003).

Berdasarkan penelitian Makosim et al. (2008) menunjukan bahwa hasil perhitungan jumlah koloni bakteri Coliform pada kue tradisional yaitu pada kue mangkok, kue talam ubi, kue putu ayu dan hunkue mutiara melebihi ambang batas yang diizinkan (SNI 01-4311-1996) yaitu $1 \times 10^{4}$ (koloni/gram). Jenis kue mangkuk, kue talam ubi, kue putu ayu dan hunkue mutiara dengan jumlah koloni bakteri Coliform $2,10 \times 10^{4}$ (koloni/gram), 20,30 $\times 10^{4}$ (koloni/gram), $29,70 \times 10^{4} \quad$ (koloni/gram dan $2,40 \times 10^{4}$ (koloni/gram). Hasil penelitian tersebut menunjukkan bahwa kue tradisional berpotensi terkontaminasi oleh bakteri Coliform.
Bakteri coliform dalam makanan menunjukkan kemungkinan adanya mikroba enteropatogenik dan toksigenik yang berbahaya bagi kesehatan (Widianti \& Ristianti, 2004). Perhitungan mikroba dapat dilakukan dengan uji hitung jumlah bakteri dengan metode Metode MPN (Most Probable Number) ( Pratiwi,2008). MPN (Most Probable Number) merupakan uji yang mendeteksi sifat fermentatif Coliform dalam sampel, MPN terdiri dari uji pendugaan (Presumptive test), uji penegas (Confirmed test) (Suriawiria, 2005). Kualitas mikrobiologi makanan dapat ditentukan berdasarkan nilai MPN Coliform. Berdasarkan Peraturan Kepala BPOM nomor 16 tahun 2016 syarat batas maksimal total bakteri Coliform 11 MPN/g (SNI ISO 7251:2012).

Kue bingke berendam yang dipilih untuk penelitian ini adalah jenis bingke berendam yang memiliki tekstur lebih berair atau basah. Komposisi suatu bahan pangan menentukan jenis mikroorganisme yang dapat tumbuh dengan baik. Tekstur bingke yang lebih berair dapat menyebabkan kerusakan oleh mikroorganisme seperti bakteri (Serrazanetti et al, 2013). Keberadan bakteri didukung oleh kandungan nutrisi pada makanan tersebut yang menguntungkan untuk pertumbuhan bakteri. Berdasarkan hal tersebut perlu dilakukan penelitian untuk mengetahui cemaran bakteri golongan Coliform pada kue bingke berendam berdasarkan Angka Paling Mungkin (APM)/Most Probable Number (MPN). 


\section{BAHAN DAN METODE}

\section{Waktu dan Tempat Penelitian}

Penelitian ini dilakukan selama 2 bulan, dimulai pada bulan September hingga oktober 2017, yang mencakup pengambilan sampel di lapangan, pengujian sampel dan analisis data. Pengambilan sampel bingke dilakukan di lima toko kue bingke di Kota Pontianak. Analisis data dilakukan di Laboratorium Mikrobiologi, Jurusan Biologi, Fakultas Matematika dan Ilmu Pengetahuan Alam Universitas Tanjungpura, Pontianak.

\section{Bahan}

Bahan yang digunakan pada penelitian ini adalah alkohol $70 \%$, alumunium foil, akuades, Brilliant Green Lactose Bile Broth (BGLB), kue bingke, Lactose Broth (LB), spiritus.

\section{Prosedur Kerja}

Sterilisasi Alat

Alat-alat kaca berupa cawan petri, gelas beker, gelas ukur dan tabung reaksi dicuci bersih terlebih dahulu lalu dikeringkan dan disterilisasi menggunakan autoklaf dengan tekanan 2 atm dan suhu $121^{\circ} \mathrm{C}$ selama 15 menit (Marlina, 2008).

\section{Pengambilan Sampel}

Pengambilan sampel bingke diambil pada lima toko di Kota Pontianak. Kue bingke diambil sebanyak 3 kue dari masing-masing toko. Sampel kemudian dimasukkan ke dalam plastik dan cooling box, kemudian dibawa ke Laboratorium Mikrobiologi, Fakultas Matematika dan Ilmu Pengetahuan Alam, Universitas Tanjungpura, Pontianak untuk dianalisis cemaran Coliform.

\section{Pengenceran}

Sampel yang telah diambil dari masing-masing toko dikompositkan dengan cara 3 kue bingke dihancurkan menggunakan blender. Sampel sebanyak $10 \mathrm{~g}$ diambil dan dimasukkan ke dalam erlenmeyer yang berisikan $90 \mathrm{ml}$ akuades sebagai suspensi. Sebanyak $1 \mathrm{ml}$ diambil dan dimasukkan ke dalam tabung reaksi yang berisikan $9 \mathrm{ml}$ akuades sebagai pengenceran $10^{-1}$, kemudian dihomogenkan menggunakan vortex, selanjutnya dibuat pengenceran $10^{-2}$ dan $10^{-3}$ dengan cara yang sama (Waluyo,2008).

\section{Pengujian Bakteri Coliform}

Pengujian ini dilakukan dengan metode MPN melalui dua tahapan yaitu Uji Penduga (Presumtif Test) dan Uji Konfirmasi (Confirmative Test) (Nugroho, 2006):
Uji Penduga (Presumtif Test)

Sampel hasil pengenceran $10^{-1}, 10^{-2}$ dan $10^{-3}$ diambil sebanyak $1 \mathrm{ml}$ dan masing-masing dimasukkan ke dalam 3 tabung yang berisi $9 \mathrm{ml}$ media Lactose Broth (LB). Selanjutnya setiap tabung yang berisi sampel diinkubasi selama 24-48 jam dengan suhu $37{ }^{\circ} \mathrm{C}$. Setelah diinkubasi jumlah tabung yang terdapat gas diamati dan dicatat kemudian diuji dengan uji penegas.

\section{Uji Penegas (Confirmative Test)}

Sampel di dalam tabung diambil sebanyak 1 ose, dan dipindahkan ke dalam tabung yang berisi $9 \mathrm{ml}$ media Brilliant Green Lactose Bile (BGLBB) dan dilengkapi dengan tabung durham terbalik. Seluruh tabung diinkubasi pada suhu $37{ }^{\circ} \mathrm{C}$ selama $24-48$ jam. Uji dinyatakan positif jika terbentuk gas atau gelembung dalam tabung durham. Dicatat jumlah tabung yang terbentuk gas pada uji penegas dan disesuaikan dengan tabel Most Probable Number (MPN) (SNI 7388:2009). Jumlah angka yang didapatkan pada tabel MPN menunjukan jumlah bakteri coliform dalam tiap $\mathrm{g} / \mathrm{ml}$ sampel yang diujikan.

\section{Analisis dan Penyajian Data}

Penelitian ini bersifat observatif dan deskriptif. Data yang diperoleh didokumentasikan dan dideskripikan berasarkan hasil pengujian di laboratorium serta pengamatan faktor kebersihan lingkungan.

\section{Hasil dan Pembahasan}

\section{Hasil \\ Pengujian Bakteri Golongan Coliform dengan Metode MPN Pada Sampel Kue Bingke Berendam}

Berdasarkan pengujian bakteri golongan Coliform yang telah dilakukan pada uji penduga dan penegas menunjukan hasil positif dengan adanya gelembung gas yang dihasilkan pada tabung durham (Gambar 2).

Hasil pengamatan menunjukan bahwa nilai MPN bakteri golongan Coliform pada kue bingke berendam di kota Pontianak yaitu Pontianak Kota $>1100$ (MPN/g), Pontianak Barat 1100 (MPN/g), Pontianak Selatan 23 (MPN/g), Pontianak Timur 43 (MPN/g) dan Pontianak utara >1100 (MPN/g) (Tabel 3). Hal ini menunjukkan bahwa nilai MPN pada kue bingke berendam di kota Pontianak melebihi ambang batas cemaran bakteri Coliform yang ditentukan, yaitu syarat batas maksimal total bakteri yang ditetapkan oleh Peraturan Kepala BPOM nomor 16 tahun 2016 adalah 11 APM/g (SNI ISO 7251:2012). 


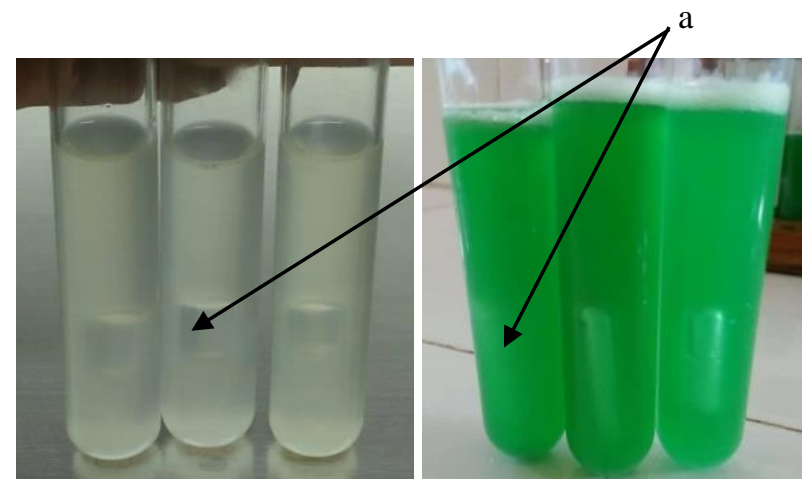

Gambar 2. Uji penduga dan uji penegas

Keterangan: a. Uji positif ditandai dengan terbentuknya gas pada tabung durham

Tabel 3 Nilai MPN Bakteri Coliform Pada Sampel Kue Bingke Berendam

\begin{tabular}{cccc}
\hline Pontianak & $\begin{array}{c}\text { Coliform } \\
\text { (MPN/g) }\end{array}$ & $\begin{array}{c}\text { Standar } \\
\text { Coliform } \\
\text { (MPN/g) }\end{array}$ & Keterangan \\
\hline Kota & $>1100$ & 11 & TMS \\
Barat & 1100 & 11 & TMS \\
Selatan & 23 & 11 & TMS \\
Timur & 43 & 11 & TMS \\
Utara & $>1100$ & 11 & TMS \\
\hline
\end{tabular}

Keterangan : TMS = Tidak Memenuhi Syarat MS = Memenuhi Syarat

\section{Pembahasan}

\section{Pengujian Bakteri Coliform dengan Metode MPN Pada Sampel Kue Bingke Berendam}

Pemeriksaan bakteri Coliform dengan metode MPN dilakukan melalui uji penduga (presumtive test) dan uji penegas (confirmative test). Media yang digunakan untuk uji praduga adalah Lactose Broth (LB). Media ini mengandung laktosa yang yang menyediakan sumber karbohidrat yang dapat difermentasi untuk bakteri golongan Coliform. Hasil positif pada uji ini dapat dilihat dari pembentukan gas pada tabung durham. Uji konfirmasi menggunakan media BGLB yang dapat menghambat pertumbuhan bakteri yang tidak hidup dalam saluran pencernaan manusia dan mengahambat pertumbuhan bakteri gram positif dan negatif selain Colifom (Fardiaz, 1989).

Berdasarkan hasil (Tabel 3) dapat diketahui bahwa dari lima sampel bingke yang diuji semuanya tidak memenuhi syarat batas maksimal total bakteri golongan Coliform yang ditetapkan oleh PERKA BPOM nomor 16 tahun tahun 2016, yaitu dengan syarat maksimal $11 \mathrm{MPN} / \mathrm{g}$ (SNI ISO 7251:2012). Beberapa faktor diduga menjadi penyebab nilai MPN bakteri golongan Coliform pada sampel kue bingke berendam, antara lain lama pemajangan, kebersihan pedagan atau penjamah seperti mencuci tangan, memakai sarung tangan, memakai masker, memakai penutup kepala dan memakai celemek serta kebersihan lingkungan tempat penyajian.

Lama pemajangan mempengaruhi kualitas kue karena kue bingke dapat mengalami perubahan fisik dan kimia. Kondisi meja atau etalase pemajangan kue bingke dan lokasi penjualan yang berada di tepi jalan juga dapat mempengaruhi kontaminasi bakteri. Contohnya sampel kue bingke di Pontianak Barat menurut informasi yang diberikan oleh penjual masih menjual bingke yang sehari sebelumnya yang tidak laku, sehingga memiliki waktu pemajangan yang lebih lama, kondisi kue bingke yang saat dibuka terkontaminasi oleh serangga seperti semut, sehingga kebersihan yang kurang terjaga memungkinkan telah terjadi kontaminasi. Menurut Nurjanah (2006), kontaminasi juga dapat terjadi jika penyimpanan atau pemajangan makanan terlalu lama. Penyimpanan yang lama akan menyebabkan tumbuhnya bakteri patogen seperti coliform. Adapun syarat-syarat tempat pengolahan makanan yang baik adalah memenuhi syarat kesehatan, selalu bersih, terlindung dari insekta dan binatang pengerat lainnya (Yunita \& Dwipayanti, 2010).

Berdasarkan hasil observasi kelima toko kue bingke berendam diketahi bahwa lokasi penjualan berada di tepi jalan dan selokan dan terdapat vektor pembawa mikroorganisme seperti semut. Menurut penelitian yang dilakukan Ginting (2005) terhadap pedagang burger kaki lima ternyata tempat penjualan berada dekat sumber pencemaran seperti debu, asap dan serangga. Hal ini memungkinkn kue bingke berendam yang dijual untuk lebih banyak terkontminasi oleh bakteri. Bakteri coliform merupakan mikroorganisme yang sering digunakan sebagai indikator untuk menentukan suatu sampel terkontaminasi patogen atau tidak.

Sanitasi yang kurang baik dari pedagang atau penjamah makanan juga dapat menjadi sumber penyakit. Perannya dalam suatu penyebaran penyakit dengan cara kontak antara pedagang dengan makanan, penanganan makanan oleh pedagang yang sakit, misalnya batuk atau memiliki luka di tangan atau pembawa bakteri. Higiene peorangan penjamah makanan sangat mempengaruhi terjadinya pencemaran oleh bakteri. Keberadaan bakteri pada tangan penjamah makanan dapat terjadi karena setelah buang air besar, penjamah makanan tidak mencuci tangan dengan bersih (Taylor et al, 2002). Berdasarkan hasil observasi pada kelima toko kue bingke diketahui bahwa semua pedagang yang tidak memakai sarung tangan, tidak mencuci tangan dengan sabun setiap 
kali akan menangani kue bingke, masker, celemek, tutup kepala. Menurut Rahayu dan Sudarmiji (1989), tangan merupakan sumber utama kontaminasi mikroba jika kontak langsung dengan makanan maupun minuman. Mikroba ini dapat berasal dari feses normal ataupun penderita diare yang umumnya dari kelompok bakteri Coliform. Pedagang yang tidak menggunakan masker dapat menyebarkan mikroba yang berasal dari rongga hidung, mulut dan tenggorokan melalui hembusan nafas, contohnya bakteri golongan Coliform seperti anggota genus Klebsiella.

Penggunaan celemek bertujuan melindungi makanan dari kontaminasi mikroba dari pakaian yang tidak bersih (Purnawijayanti, 2005). Menurut Moehyi (1992), mikroba yang melekat pada pakaian apabila tersentuh oleh tangan dapat menyebabkan tangan juga ikut terkontaminasi. Agustina et al. (2009) menyatakan bahwa sentuhan tangan merupakan penyebab yang paling umum terjadinya pencemaran makanan. Mikroorganisme yang melekat pada tangan akan berpindah ke dalam makanan dan akan berkembang biak dalam makanan. Pakaian yang tidak bersih dapat mengandung bakteri yang berasal dari debu atau kotoran yang melekat dapat menyebabkan pencemaran mikroba pada makanan. Menurut Rahmadhani \& Sumarmi (2017), penutup kepala sebaiknya digunakan untuk mengurangi resiko pencemaran fisika, kimiawi dan biologi terhadap makanan yang mungkin terbawa dari penjamah makanan.

Lokasi tempat penjualan kue bingke berendam pada kelima toko kue berada di tepi jalan dan tepi parit/selokan. Hal ini juga dapat mempengaruhi kontaminasi pada kue bingke berendam. Peralatan yang digunakan tidak dicuci sebelum digunakan dan dibiarkan di ruangan terbuka. Faridz et al. (2007) menyatakan bahwa kotoran yang tertinggal pada peralatan berasal dari debu polusi udara akibat dari penyimpanan peralatan di ruangan terbuka. Penyimpanan di ruangan terbuka juga dapat menyebabkan peralatan yang digunakan dapat terkontaminasi oleh vektor pembawa mikroorganisme seperti lalat, sehingga kemungkinan untuk lebih banyak terkontaminasi oleh bakteri.

\section{DAFTAR PUSTAKA}

Agustina F, Pambayun R \& Febry F, 2009, 'Higiene dan Sanitasi pada Pedagang Makanan Jajanan Tradisional di Lingkungan Sekolah Dasar di Kelurahan Demang Lebar Daun Palembang tahun 2009', Jurnal Ilmiah Fakultas Kesehatn Masyarakat Universitas Sriwwijaya
Balia, R.L., E. Harlia, \& D. Suryanto, 2008, Jumlah Bakteri Total dan Koliform pada Susu Segar Peternakan Sapi Perah Rakyat dan Susu Pasteurisasi Tanpa Kemasan di Pedagang Kaki Lima, Fakultas Peternakan Universitas Padjadjaran, Bandung.

Depkes Republik Indonesia, 2002, Grafik Presentase Sumber Keracunan Makanan 1997-2000, Direktorat Penyehatan Makanan dan Sanitasi Dirjen PPM \& PL, Jakarta

Dinas Peternakan Provinsi Jawa Barat, 2003, Standar Susu Segar. Kegiatan Standarisasi dan Penerapan Sistem Jaminan Mutu Produk Peternakan, Dinas Peternakan Provinsi Jawa Barat, Bandung

Djaja, I,M, 2003, 'Kontaminasi E.coli pada makann dari tiga jenis tempat pengelolaan makanan (TPM) di jakarta selatan', Jurnal Makalah Kesehatan, Vol.12, Hal. 36-41

Entjang I, 2003, Mikrobiologi dan Parasitologi untuk Akademi Keperawatan dan Sekolah Tenaga Kesehatan yang Sederajat,Citra Adtya Bakti, Bandungadaan Escherichia coli Pada Pengolahan Ikan Teri Nasi PT. Kelola Mina Laut Unit Sumenep, Skripsi, Universitas Trunojoyo, Madura

Fardiaz, 1989, Analisis Mikrobiologi Pangan, Departemen Pendidikan dan Kebudayaan IPB, Bogor

Faridz, R, Hafiluddin, \& M, Anshari, 2007, Analisis Jumlah Bakteri Dan Keberadaan Escherichia coli padaPengelolahan Ikan Teri Nasi PT. Kelola Mina Laut Unit Sumenep', Skrpsi, Universitas Trunojoyo, Madura

Ginting EP, 2005, Kandungn Bakteri Escherichia coli dan Salmonella sp. pada Daging Burger yang Dijual di Sekitar Kampus USU Medan Tahun 2005, Skripsi, Fakultas Kesehatan Masyarakat Universitas Sumatra Utara, Medan

Marlina, 2008, 'Identifikasi Bakteri Vibrio parahaemolitycus dengan Metode Biologi dan Deteksi Gentoxrnya Secara PCR', Jurnal Sains dan Teknologi Farmasi vol. 13, no.1, hal. 11-17

Makosim S, Kadir I dan Indahswari R, 2008, Uji Cemaran Mikroba (Aerob, Coliform, Staphylococcus sp, dan Khamir) Pada Makanan Jajanan (Snack), Prosiding Seminar PATPI Palembang

Moehyi S, 1992, Penyelenggaraan Makanan Institusi dan Jasa Boga, Bhratara, Jakarta

Nugroho, A, 2006, Bioindikator Kualitas Air, Cetakan 1, Universitas Trisakti, Jakarta

Nurjanah, S, 2006, 'Kajian sumber cemaran mikrobiologis pangan pada beberapa rumah di lingkar kampus IPB Darmaga', Jurnal Ilmu Pertanian Indonesia, vol.11 no.3, hlmn 18-24 
Pratiwi, Sylvia T, 2008, Mikrobiologi Farmasi, Erlangga Jakarta

Purnawijayantu HA, 2005, Sanitasu Higiene dan Keselamatan Kerja dalam Pengolahan Makanan, Kansius, Yogyakarta

Rahmadhani \& Umarmi, 2017, Gambaran Penerapan Prinsip Higiene Sanitasi Makanan Si PT Aerofood Indonesia, Tanggerang, Banten

Rahayu K \& Sudarmiji, 1989, Mikrobiologi Pangan, pusat Antar Universitas Pangan dan Gizi, UGM, Yogyakarta

Serrazanetti DI, Ndagijimana M, Miserocchi C \& Guezoni M.E, 2013, Fermented tofu : Enhancement of keeping quality and sensorial proerties, Food Control 34:336-346

Suriawiria, U, 2005, Mikrobiologi Dasar, Papas sinar sinanti, Jakarta

Taylor, H, Brown K, Toivenne J, 2002, 'A Microbiological Evalution of Warm Air Hand Driers with Respect to Hand Hygiene and The Washroom Environment', Journal Appl Microbiol, 89, pp. 9-910

Widiyanti NLPM \& Ristiati NP, 2004 Analisis Kualitatif Bakteri Coliform Pada Depu Air Minum Isi Ulang Di Kota Sibgaraja Bali, Jurnal Ekologi Kesehatan, vol. 3 , no.1, hal.68

Yunita, NLP, Dwipayanti, NMU, 2010, 'Kualitas Mikrobiologi Nasi Jinggo Berdasarkan Angka Lempeng Total, Coliform Total Dan Kandungan Escherichia coli', Jurnal Biologi XIV (1) hlm 9-1 